\title{
The Changing Role of Nation-state
}

\author{
Yongxiu Zhou \\ Department of Foreign Language Teaching and Research, Taishan University \\ Tai'an 271021, Shandong, China \\ E-mail: yongxiuzhou@sina.com
}

Received: April 3, 2011 Accepted: April 30, $2011 \quad$ doi:10.5539/ijel.v1n2p269

\begin{abstract}
As the process of globalisation and the development of ICT accelerate, the role of nation-state is changing dramatically in that their rules of sovereignty are "increasingly more conditional, negotiable, and complex". But there is little evidence that nation-state is diminishing, being converged into supra-nation or diverged into sub-nation. Nationalism, which is always fluctuating with the historical tides, has been well alive in its new disguise.
\end{abstract}

Keywords: Nation-state, Globalisation, Nationalism, War, Global governance

\section{Scientific History}

When Negroponte (1996:236) asserts that "the role of the nation-state will change dramatically and there will be no more room for nationalism than there is for smallpox", we realise that he is right with his self-comment that "I think of myself as an extremist when it comes to predicting and initiating changes" (Negroponte, 1995:75).

The scientific history has demonstrated that many scientific and technological development and/or application go against the wills of their discoverers or initiators. A good case in point is the birth of A-bomb. At the time, most of the scientists didn't imagine that they were contributing to inventing a nuclear weapon until the fall of 1939 when Albert Einstein signed a letter to President Roosevelt explaining the danger of atomic bombs and urging that the US take a lead in their production.

We have no evidence that Einstein knew that his second paper in which he introduces the famous special relativity on relation between mass and energy would be used to develop a nuclear weapon, which prompted the end of the Second World War.

But today when working in his advanced lab, Negroponte is well conscious that he is helping to enhance the military power of his nation-state, so as to win any war the USA gets involved in. Ironically, when he and his team are making every effort to defend "American nationalism", he, at the same time, is trying to convince other peoples and nation-states that nationalism is outmoded.

Then, two crucial questions spring to mind: What's war? Is it always related to nationalism? As far as we understand, in many (although not all) cases, war results from or is fuelled by certain extreme nationalism, mobilised by nation-states.

Now let's come back to the development of modern communication technology. It's well known that both Internet and multimedia were brought into being on military purposes (Negroponte, 1995:65-67). In his book Being Digital (1995), Negroponte mentioned that many of his technologies are intended to upgrade military service, which suggests that many of his research projects are funded by the American army. What's more, he $(1995: 227)$ has already realised that "every technology or gift of science has a dark side. Being digital is no exception".

\section{Possible Origins}

About the origins of nation-state and nationalism, there are at least two opposite ideas. Some tend to believe that nationalism is an artefact, created by men under certain conditions (Hammar, 1990:61), just as Anderson (his emphasis, as cited in Hammar, 1990:61) says: "Nationalism is not the awakening of nations to self-consciousness: it invents nations where they don't exist."

Others argue that "there have always existed, since history began, peoples or nations and that these peoples, often themselves unaware of their nationality, can be made self-conscious by mobilization" (Hammar, 1990:61).

When addressing the possible trajectories of nation-state and nationalism, we will unavoidably ask: Will the European nation-states give way to the European Union? 
What made the member countries decide on "the voluntary surrender by the nation-states of specific areas of national sovereignty to the Community's own political structure"? (Milward, 2000:7) Is the European Union an intrinsic phase of the evolution of human society as Karl Marx predicted?

In this field, "History has conquered theory, but it has done so in an entirely negative way" (Milward, 2000:18). For historians working on the diplomatic records in the conventional mode of diplomatic history began to present European integration as an aspect of national diplomacy: "Far from appearing as the response to powerful and inevitable economic change, or to a large-scale popular conversion to belief in a united Europe, it appeared as a diplomatic manoeuvre." (Milward, 2000:17)

Walter Lipgens (as cited in Milward, 2000:15) further pointed out that the concept of European unity developed strongly in opposition to the Nazi "world-outlook". The realization of the extent of the weakness of the European nation-states in comparison to the two post-war superpowers then strengthened the small separate movements in favour of European unity and fused them into a single movement in 1947.

In this context, we have to agree that "Integration was not the supersession of the nation-state by another form of governance as the nation-state became incapable, but was the creation of the European nation-states themselves for their own purpose, an act of national will" (Milward, 2000: 18). Then, will European nation-states eventually disappear, to be converged into a political supra-nation? Our answer is definitely "No."

History has demonstrated that the European unity is an instrument by which its member countries can maximise their own national interests. Also, the nation-states only surrender limited areas of sovereignty to the supra-nation (Milward, 2000: 4). We prefer to believe that, otherwise, these nation-states would rather launch the third world war to defend their basic national interests.

At the same time, it has been more popularly agreed that the European Community political system rested on national systems, especially that of the Federal Public. In this light, Milward (2000: 3) famously concluded that "To supersede the nation-state would be to destroy the Community. To put a finite limit to the process of integration would be to weaken the nation-state, to limit its scope and to curb its power."

\section{Nationalistic War}

What are the underlying causes of war? Among the various assumptions, we tend to believe the following three are the major causes:

First, "War results primarily from the tendencies of capitalist states to expand markets, investment opportunities, and raw materials", according to Marxist-Leninists (Levy, as cited in Kegley Jr. \& Wittkopf, 1992:62), albeit that many western powers wouldn't acknowledge this.

Second, many of the modern wars are related to "security dilemma", as illustrated by Levy (as cited in Kegley Jr. \& Wittkopf, 1992:65) as follows:

Given this uncertainty, political leaders prefer to err on the side of safety

and engage in worst-case analysis. They recognize that false pessimism

regarding the adversary's intentions might lead unnecessarily to a further

escalation of tensions, but they fear that the consequences of a false optimism

would be even worse. Thus even actions that are purely defensive in intent are

often perceived as threatening by another state and lead it to take actions that

leave all states worse off than before.... If the nature of military technology is

such as to give a major advantage to the state that strikes first in a crisis, states

can be induced to initiate a preemptive attack even though both sides would

prefer to avoid war.

Third, war has been considered by so many political leaders as a means to solve domestic problems, on the assumption that external conflict will promote internal harmony (Kegley Jr. \& Wittkopf, 1992:62). This has been famously noted by Elizabeth I (as cited in Green, 1997:2) that national unity could be won through facing a common enemy abroad.

On the whole, there is no natural limit to the pursuit of power and security, and this is the major reason why

states have been fighting wars for millennia, and in spite of the

enormous technological, economic, political, and cultural changes

over the ages, there is little evidence that war will soon cease to exist

as a regular pattern of behaviour in world politics (as cited in Green, 1997: 61). 
The difference is that today, the country who strikes first will make every attempt to justify and legitimate his attack in order to distance itself from "official terrorism", as Kitson (1971: 78, as cited in Schlesinger, 1991:17) summarised:

The government must promote its own cause and undermine that

of the enemy by disseminating its view of the situation, and this

involves a carefully planned and co-ordinated campaign of what

for want of a better word must regrettably be called psychological

operations.

Compared with war, "symbolic violence" is more commonplace on the international stage. According to the French sociologist Pierre Bourdieu (1977:196, quoted in Schlesinger, 1991:14), "Symbolic violence is the gentle, hidden form which violence takes when overt violence is impossible". Later, the German communication theorist Harry Poss (1981:69, his emphases, as cited in Schlesinger, 1991:14) defined it as "the power to make so effective the validity of meaning through signs that others identify themselves with it". It offers an alternative to physical coercion where political circumstances permit, but it is still likely to induce a war under certain conditions.

\section{Link 1: Do you recognise the stereotypes?}

UN once conducted a survey around the world. The question was "Please express your honest opinion about solving the problem of food shortage in other countries".

The survey failed because in Africa the majority of respondents didn't know what "food" meant, Eastern Europeans didn't know what "honest" meant, Western Europeans didn't understand the word "shortage", Chinese didn't understand the word "opinion", in the Middle East they didn't have a clue what "solving the problem" meant, in Southern Africa they didn't know the meaning of the word "please" and in the US none knew what "other countries" meant.

This partially justifies the increasing significance of international ideology as well as international media and communication. Let's take USA for example. The September 11 attacks made most American political leaders realise that the internal security is seriously affected by external disorder. The problems in Africa and Middle East may become the seeds of terrorism and entail the spread of weapons of mass destruction, which, sooner or later, will endanger the USA's security. In this case, it's vitally necessary to reconstruct those problematic countries to stem any potential hazards to USA (note 1). The Second Gulf War is only the first application of this ideology.

\section{Economic Globalisation}

The global flow of investment, technology, communications, and profits are seen as the most striking symptom of global challenge to the nation-state. But we believe that nation-state and multinational enterprises (MNEs) need each other. Put it simply, the MNEs need nation-states to deliver high levels of political stability, infrastructural and fiscal support. In addition, extraction-based MNEs have fewer alternatives than manufacturing-based MNEs. Namely, not all MNEs can threaten to exit from a particular country.

But the problem is that MNEs make decisions on the basis of optimising the private profitability of the corporation rather than the economic health of particular nations. Also, MNEs penetration of local markets often puts local producers out of business or inhibits the entry of domestically owned competitors into sectors of MNE domination (Holton, 1998:95).

What's more, MNEs are often unwilling to share firm-specific intellectual property and technological and managerial skills with national competitors (Carnoy, quoted in Holton, 1998:95). In fact, the MNEs home-based governments, especially USA, often serve to compound this situation in areas such as intellectual property rights and control of certain types of sophisticated technology transfer (Hilton, 1998: 95). Even when Negroponte was writing his famous Being Digital (1995), he (1995:1) admitted that "I found myself in the middle of a heated national debate about the transfer of technology from U.S. research universities to foreign companies". He (1995: 2) informed us that he was summoned to two industry-government meetings to discuss "the protection of American computer industry and our electronic competitiveness".

Worse, when many nation-states were left little alternative but to "fall deeper into the waiting arms of technology-bearing, capital-laden multinational firms" (Carnoy, as cited in Holton, 1998:92), they found with surprise as well as disappointment that "The gap between the advanced economies and the non-advanced economies, broadly between the North and the South, has widen rather closed, and even among the advanced economies there is continuing divergence on a number of indices" (Green, 1997:161).

All the aforementioned factors have, to different degrees, contributed to the "the case that modern ethnic nationalisms emerge in undeveloped states or among disadvantaged groups in developed states" (Hobsbawn, as cited in Green, 1997:164). This in turn, at least partially, accounts for why MNEs need the ideology of economic 
liberalism and free trade, and more importantly, why the post-war global capitalist economy has depended on the military and political support of the USA as a superpower (Gilpin, as cited in Holton, 1998:94).

\section{International Agencies}

It has been observed that a host of international agencies have acquired significant powers, and states have bound themselves, to some extent at least, to uphold and implement their decisions (Green, 1997:165). But this doesn't necessarily mean the net loss of sovereignty. On the contrary, "nation-states are the very building blocks of international governance. Without them, international agencies would either not exist, or would have no legitimacy or means of enforcement" (Green, 1997:165).

Green (1997:168) even claimed that "Taken over a long term, the reach of governmental control has probably increased, not diminished". His main reasons are: Firstly, when governments have to cede some direct responsibility, they become active in some other areas. Secondly, nation-states, in most cases, voluntarily submit part of their autonomy to supra-nation in order to maximise their national benefits. Thirdly, as communication technology develops, the potential for state surveillance and monitoring has vastly augmented.

\section{IT Development}

Negroponte (1995:7) asserted that

As we interconnect ourselves, many of the values of a nation-state

will give way to those of both larger and smaller electronic communities.

We will socialize in digital neighbours in which physical space will be

irrelevant and time will play a different role.

Pieterse (as cited in Green, 1997:156) also noted that "global communications can be a force for both fragmentation and unification, ... reinforcing both supranational and subnational regional identities". This process, termed by Ronald Robertson as "glocalization", takes the forms of homogenisation and hetrogenization at the same time.

As IT develops, the controlling capacity of nation-state will vastly increase, the "bit police" will become more active and efficient in our daily life. In other words, schemes to weaken the nation-state will be more likely to be detected and stopped in time.

Meanwhile, as the modern war becomes digitalized, new communication technology will heighten the status of nation-state by increasing its own military power and decreasing that of its adversary's.

\section{Conclusion}

We agree that "nationalism is a style of imaging a political community" (Anderson, as cited in Hammar, 1990:61), and that nationalism is only a tool in the eyes of political leaders.

In agrarian societies, the ruling classes emphasise cultural differentiation in their interests, and they have no wish to promote cultural homogeneity among the regionally divided peasants (Hammar, 1990:64). The change came with industrialisation, which depended on mobile and exchangeable individuals, able to communicate in a standardized way. In our information age, the global powers find that nationalism is one source of the strong resistance to global market. Meanwhile, "the most ardent supporters of the European Union denounce the nation-states as an anachronistic barrier to the final achievement of a more advanced stage of government and society, the supranation" (Milward, 2000:2).

A case in point to illustrate how the Western powers treat nationalism as an instrument is their policy about the Soviet Union, just as Urban (1991:226) reveals:

It was "only yesterday" that we saw the tyrannical Soviet Empire as the

principal danger to the rest of the world, and we looked upon anything that

might weaken that centralized tyranny — especially the spread of nationalism

in the non-Russian parts of the empire - as deserving support. It was, we said,

in the universal interests of freedom that we should recognize and promote

these nationalism. The risk that they might eventually get out of hand and

follow the Mazini-or Mickiewicz - type of $19^{\text {th }}$-century European nationalism

struck us as much smaller than the risk of allowing the Soviet system to

continue".

Another reason why we think nationalism will not be withering away is in the psychological dimension. Stephenson said (19972:2) that "It is that our whole framework of thought and reaction is founded in the 
sixteenth-century concept of the sovereign nation-state. Outside that framework, as individuals, we know no points of reference."

\section{Link 2: The Best Doctor}

A British doctor says: "Medicine in my country is so advanced that we can take a brain out of one man, put it in another and have him looking for work in six weeks."

A German doctor says: "That's nothing, we can take a brain out of one person, put it in another and have him preparing for war in four weeks."

The American doctor, not to be outdone, says: "You guys are way behind, we just took a man with no brain out of Texas, put him in the White House, and now half of the country is looking for work, and the other half preparing for war."

Vaclav Havel (as cited in Green, 1997:163-164), in his 1994 speech on receiving the Philadelphia Liberty Medal in Independence Hall has stressed the essential psychological limitations of a superficial global culture:

Our civilisation has essentially globalized only the surface of our

lives. But our inner Self continues to have a life of its own and the

fewer answers the era of rational knowledge provides to basic questions

of human being, the more deeply it would seem that people, behind its

back as it were, cling to the ancient certainties of the tribe. Because of

this, individual cultures, increasingly lumped together by contemporary

civilization, and realizing with new urgency their own inner autonomy

and the differences with others.

As for the increase in cultural contacts between countries, Milward (2000:14) argues resoundingly that it was "a symptom of the growing self-confidence of the nation-state, rather than one of the process which was weakening it."

Green (1997:165) concluded that

For the foreseeable future, at least, it would seem that there will continue to

be a dichotomous patter of increasing cultural globalisation including

deepening cosmopolitanism in some states and escalating cultural nationalism

in others.

In a word, we agree that "It is still too early to judge the long-term outcome of many of the recent trends, and the data are, as yet, insufficient to judge the pervasiveness of even current trends". As for the future of nationalism, if we must make a choice between "decreasing" and "increasing", we would prefer the latter.

\section{References}

Green, A. (1997). Education, Globalisation and the Nation State. UK: MACMILLAN PRESS LT \& USA: ST. MARTIN'S INC.

Hammar, T. (1990). Democracy and the Nation State. Avebury.

Harvey, D. (1990). The Condition of Postmodernity. Blackwell.

Holton, R.J. (1998). Globalization and the Nation-State. UK: MACMILLAN PRESS LT \& USA: ST. MARTIN'S INC.

Kegley Jr., C.W. \& Wittkopf, E.R. (1992). The Global Agenda-Issues and Perspectives (Third Edition). Mcgraw-Hill, Inc.

Kedourie, E. \& Urban, G. (1991). What's wrong with 'nationalism'? What's right with the 'balance of power', In Ra'anan, Uri et al (eds.) State and nation in multi-ethnic societies. Manchester University Press.

Milward, A.S. (2000). The European Rescue of the Nation-State ( $2^{\text {nd }}$ Edition). Routledge.

Negroponte, N. (1995). Being Digital. Hodder \& Stoughton.

Schlesinger, P. (1991). Media, State and Nation. SAGE Publications.

Stephenson, H. (1972). The Coming Clash-The Impact of International Corporation on the Nation State. Wiedenfeld and Nicolson.

\section{Note}

Note 1. Sing Tao Daily (European Edition), March 26, 2003, page B4 